\title{
Government And Taxpayers Interests' Coordination Model Within The CGT, Based On The Principle Of Social And Economic Efficiency
}

\author{
Kristina A. Bannova \\ Department of Management \\ National Research Tomsk Polytechnic University \\ Tomsk, Russia \\ bannovaka@yandex.ru \\ Natalia V. Pokrovskaia \\ Department of Credit Theory and Financial Management \\ Saint-Petersburg State University \\ Saint Petersburg, Russia
}

\author{
Irina N. Dolgikh \\ Department of Management \\ National Research Tomsk Polytechnic University \\ Tomsk, Russia
}

\author{
Alena A. Kropova \\ Department of Management \\ National Research Tomsk Polytechnic University \\ Tomsk, Russia
}

\begin{abstract}
The ways of raising the efficiency of taxation become increasingly important at the present stage of development of the Russian Federation. Existing calculating the tax base methods, the rate of tax revenues to the budgets, the relationship between taxpayers and tax authorities have a direct impact on the development of the country and regions. Through effective tax administration, redistribution process of monetary resources into social, defense, environment protection sphere occurs. Thus, a high degree of tax efficiency creates the basic conditions for social and economic development of Russia and its regions.

In order to increase regions income, to encourage the conditions to compete for Russian companies on national and world markets, to develop socio-economic sphere of the country, the concept of a consolidated group of taxpayers was introduced with Russian Federal Law of November 16, 2011 N 321-FZ "On Amendments to Parts One and Two of Russian Federation Tax due to creation of Consolidated Group of Taxpayers". This law is to simplify the payment of income taxes by large taxpayers.

The Consolidated Group of Taxpayers (CGT) is a voluntarily tax profits association of taxpayers on the basis of the establishment of a consolidated group of taxpayers agreement with the aim of corporate income tax calculation and payment, taking into account the total financial result of these taxpayers' economic activity.
\end{abstract}

Keywords-consolidated group of taxpayers, corporate profit tax, assets, revenue.

\section{INTRODUCTION}

The decision on establishment of Consolidated Group of Taxpayers by large holdings and companies is affected by several important factors. Firstly, the possibility of redistribution of funds within the CGT increases, the possibility of the tax base reduction through consolidation of both profits and losses of the companies-members of a consolidated group of taxpayers appears. CGT is also exempt from the tax administration of transfer deals. Holding starts operating more efficiently by a synergetic effect.

The profit share of each CGT participant equals the arithmetic mean of labor resources indicator (amount or wage fund) and non-current assets (net book value of assets) as follows:

$$
d=\left(\frac{T_{i}}{\sum_{i=1}^{N} T_{i}}+\frac{A I_{i}}{\sum_{i=1}^{N} A I_{i}}\right) \cdot 1 / 2 \cdot 100 \%
$$

Where

$\mathrm{d}$ - the profit share of each participant CGT,

Ti- or the average number of labor remuneration fund of the i-th company - member CGT,

$\mathrm{N}$ - number of members CGT,

AIi - residual value of depreciable property the i-th member company CGT.

According to this method, CGT creation led to the redistribution of tax revenues between the budgets of the regions, where the main CGT production facilities and human resources are, and regions with holdings management. Precisely, there is a tax revenues reduction to the regions in which the parent companies are focused (mainly in Moscow and St. Petersburg).

In order to reconcile the government and taxpayers' interests, it is necessary to develop a model based on the principle of social and economic efficiency, and change the taxable income formation and distribution mechanism. 


\section{MAIN PRINCIPLES OF GOVERNMENT AND TAXPAYERS INTERESTS' COORDINATION MODEL WITHIN THE CGT CREATION}

The new government and taxpayers interests' coordination model within the CGT should comply with the following principles:

1) interests harmonization of the cooperating parties;

2) budget predictability;

3) equity, while equity is understood as:

- $\quad$ social and environmental equity;

- $\quad$ fiscal and legal horizontal equity;

- $\quad$ social and fiscal equity;

4) joint responsibility;

5) unity of approaches to the formation of tax liabilities;

6) organizational simplicity of the tax system;

7) transparency.

Socio-economic focus in the allocation of income tax between regions is the least implemented CGT principle in existing system of consolidated taxation in Russia. The suggested government and taxpayers interests' coordination model within the CGT creation consists of three phases at this stage. These are:

Firstly, it is necessary to take into account the contribution of each region to the economic development of the country through the creation of a system of indicators characterizing its significance;

Secondly, the coefficient approach application of establishing the value of each indicator for different sectors;

Third, in order to strengthen the principle of social justice the degree of depression of the regions, in which it operates consolidated group of taxpayers, should be taken into account the degree of depression of the regions in which it operates consolidated group of taxpayers.

III. THE FORMING STAGES OF GOVERNMENT AND TAXPAYERS INTERESTS' COORDINATION MODEL WITHIN THE CGT CREATION

\section{II.I. THE FIRST STAGE - TAKING INTO ACCOUNT THE EACH REGION CONTRIBUTION IN THE COUNTRY'S ECONOMY}

Tax revenue functionality of each region from the company, including the CGT can be described in the following model:

$$
\int_{0}^{T} \exp (-\delta t)[p(t) \mathrm{X}(t)-z(t)-w(t) L(t)] v(t) d t \rightarrow \max _{v(t)}
$$

where

$T$ - time planning horizon $t$, $\delta$ - discount coefficient

$\mathrm{X}(t)$ - output,

$p(t)$ - market price of the product,

$z(t)$ - production costs,

$w(t)$ - wage rate,

$L(t)$ - number of working employees,

$v(t)-$ tax rate.

Thus, the suggested model would reflect not only used labor resources of the region and located on the territory assets (as in the current method), but also other factors which have contributed to the interest of regional authorities in improving the enterprises functioning, to the conditions creation for the development of large (anchor) companies.

One of these indicators is value-added. In economic theory, the system of views on value-added has a number of directions. In the evaluation of the regional value-added theory is expressed as an index of GRP, which is one of the main characteristics reflecting the socio-economic situation in the subject of the Russian Federation. Innovative Development Strategy, currently implemented by the Russian Government, also requires the increase in product share with higher valueadded for the period until 2020.

Therefore, we consider it to be appropriate to put regions tax revenues in terms of income tax by CGT in dependence on the value-added amount of the company- CGT member, which is located on the territory of the region.

In general value added includes:

- Fund for compensation of employees (including contributions and extra-budgetary funds)

- Profits of the enterprise,

- Consumption of fixed capital [7].

In the existing methods of distribution of taxable income only the first and last component is used: the wage fund of workers and the residual value of depreciable property, which characterizes the consumption of fixed capital. That is why we offer to complement existing distribution from the taxable base of participants CTG another - "profits of the enterprise."

1) In determining the mechanism of calculation of this indicator should be guided by the following requirements:

2) it should characterize the economic result of the company,

3) comply with the current Russian Federation Tax Code (Chapter 25), as it will be used in income tax distribution, 
4) avoid values duplication,

5) be simple and clear definition or calculation.

Typically, the calculation of value added includes the net profit of the enterprise, which may correspond to the concept of the tax base (TB) for income taxes (excluding income tax itself). At the same time, the TB includes the taxable profit from the main activity, as well as non-operating income and expenses. The composition of the latter includes different types of income and expenses, including those that do not generate enterprise gross value added in the economic sense of this indicator. Such income and expenses will distort the real contribution of the company to the formation of the region's GRP. The structure of the gross regional income (GRI) includes the gross value added by OKVED, that is, by type of primary activity companies, which for tax purposes the figures of revenue from sales and the cost of production and sales.

Therefore, it is proposed to determine the indicator "business profits" as the profit from the principal activity of the enterprise in accordance with Chapter 25 of the Tax Code for the purpose of economically sound allocation of income tax between the parties CGT. It will be equal to the difference between the proceeds of sale (article 249 RF TC) and the cost of production and sales (article $253 \mathrm{RF}$ TC).

$$
\Pi=Д-P
$$

Where Д - income from sales (excluding VAT and excise tax), which are determined by the rules of article 249 of RF TC and consistent line 010 of the sheet 02 of the Declaration for profits tax;

$\mathrm{P}$ - production and realization costs, which are determined by the rules of the Tax Code article $253 \mathrm{RF}$ TC and match line 030 of the sheet 02 of the Declaration for profits tax.

Thus, the income tax distribution model between regions in general will look like:

$$
\int_{0}^{T} e^{-\delta t}\left[T_{i}(t)+A_{i}(t)+\Pi_{i}(t)\right] \rightarrow \max
$$

Transformations in the formula for calculating the share of taxable profits enable to assess the contribution of each CGT participant in the development of entire consolidated group.

Understanding these changes importance would give impetus to the adoption of decisions aimed at the increase of value-added of companies not only on the part of management, but also to the conditions creation for the development of enterprises by the regional authorities, as their tax revenues from CGT depend on the effectiveness of the company to the region. At the same time, this would boost the socio-economic situation of the regions and the well-being of the population.

Then we consider it is necessary to improve the model by establishing the relevance of each factor. This would let take into account the value-added of each company and the gross value-added areas more accurately.

\section{II.II. THE SECOND STAGE - THE APPLICATION OF A COEFFICIENT APPROACH.}

This method involves the establishment of the importance of each indicator for the various sectors.

The basis of the proposed model should be based on the principle of social and economic orientation, so it should be installed:

1. Factors for determining the significance of each of the indicators based on the branch structure (economic value),

2. correction factors that take into account social efficiency.

Thus, the general formula for the distribution of the consolidated income tax between regions will be:

$$
d=K_{e 1} \cdot\left[\sum_{i=1}^{n} K_{S i} \cdot T_{i}\right]^{-1} \cdot K_{s i} \cdot T_{i}+K_{e 2} \cdot\left[\sum_{i=1}^{n} A_{i}\right]^{-1} \cdot A_{i}+K_{e 3} \cdot\left[\sum_{i=1}^{n} \Pi_{i}\right]^{-1} \cdot \Pi_{i}
$$

where

$\mathrm{d}$ - share of the profits of each participant CTG, \%

$\mathrm{K}_{\mathrm{e} 1}, \mathrm{~K}_{\mathrm{e} 2}, \mathrm{~K}_{\mathrm{e} 3}$ - coefficient of economic importance for each indicator

$\mathrm{K}_{\mathrm{si}}$ - social significance coefficient (therefore set only for the value of the indicator "number").

$$
\mathrm{N} \text { - number of CGT participants. }
$$

In order to determine the coefficients of the first group the indicators reflecting the efficiency of the factors that must be distributed in proportion to the CGT tax income have been chosen:

TABLE I EFFICIENCY INDICATORS

\begin{tabular}{|l|l|l|}
\hline № & $\begin{array}{l}\text { Factors distribution of income } \\
\text { tax }\end{array}$ & $\begin{array}{l}\text { Indicators achieved } \\
\text { efficiency }\end{array}$ \\
\hline 1 & The residual value of fixed assets & Productivity of capital \\
\hline 2 & The number of employees & Working efficiency \\
\hline 3 & Operating profit & Profitability of production \\
\hline
\end{tabular}

To take into account industry-specific indicators we will analyze progress made in the CGT. By the end of 201417 groups CGT were created, $47 \%$ of which belong to the oil and gas industry (307 companies). The second place is occupied by metals: $29 \%$ or 5 members ( 51 companies), the third place - telecommunications ( $12 \%$ or 2 players), in the banking and energy sectors - 1 member CGT (Figure 2).

The figure shows the performance of the companies that make up the various CGT.

The calculations of the basic indicators of enterprises activity are presented in Table 2 . 
TABLE II THE CALCULATED DATA OF PERFORMANCE INDICATORS

\begin{tabular}{|c|c|c|c|}
\hline Company & $\begin{array}{l}\text { Productivity } \\
\text { of capital }\end{array}$ & $\begin{array}{l}\text { Working } \\
\text { efficiency, } \\
\text { mln.rub./peo } \\
\text { ple }\end{array}$ & $\begin{array}{l}\text { Profitability } \\
\text { of } \\
\text { production }\end{array}$ \\
\hline JSC "NK" Rosneft " & 0,96 & 23,86 & 0,11 \\
\hline JSC "Surgutneftegas" & 1,22 & 13,36 & 0,12 \\
\hline JSC "AK" Transneft " & 0,45 & 9,00 & 0,30 \\
\hline JSC "Tatneft" & 0,94 & 22,92 & 0,26 \\
\hline JSC "Novatek" & 1,23 & 52,98 & 0,36 \\
\hline JSC "Gazprom Neft" & 1,31 & 29,40 & 0,13 \\
\hline JSC "NK" LUKOIL " & 1,77 & 73,73 & 0,05 \\
\hline JSC "Mechel" & 1,62 & 3,08 & 0,02 \\
\hline JSC "Severstal" & 2,45 & 6,04 & 0,19 \\
\hline JSC "Novolipetsk & 1,77 & 16,43 & 0,14 \\
\hline Steel" & 3,15 & 3,97 & 0,32 \\
\hline JSC "Oskol Electric & 1,16 & 6,42 & 0,40 \\
\hline Steel Works" & 1,40 & 24,22 & 0,26 \\
\hline JSC "MMC" Norilsk & 0,91 & 1,96 & 0,13 \\
\hline Nickel " & 6,32 & 15,83 & 0,13 \\
\hline JSC "MegaFon" & 1,08 & & \\
\hline CJSC Bank VTB 24 & & & \\
\hline TOTAL & & & \\
\hline
\end{tabular}

Using the method of multidimensional comparisons as a basis, we give the total value of comparable indicators, taking into account the dispersion.

TABLE 3 THE CALCULATED AVERAGE VALUES OF PERFORMANCE INDICATORS FOR THE OIL AND GAS BRANCH

\begin{tabular}{|c|c|c|c|}
\hline Company & $\begin{array}{c}\text { Productivity of } \\
\text { capital }\end{array}$ & $\begin{array}{c}\text { Working } \\
\text { efficiency }\end{array}$ & $\begin{array}{c}\text { Profitability of } \\
\text { production }\end{array}$ \\
\hline JSC "Gazprom" & 0,113 & 0,016 & 0,418 \\
\hline JSC "NK" Rosneft" & 0,294 & 0,105 & 0,093 \\
\hline JSC "Surgutneftegas" & 0,478 & 0,033 & 0,112 \\
\hline JSC "AK" Transneft" & 0,066 & 0,015 & 0,711 \\
\hline JSC "Tatneft" & 0,281 & 0,097 & 0,531 \\
\hline JSC "Novatek" & 0,480 & 0,516 & 1,000 \\
\hline JSC "Gazprom Neft" & 0,545 & 0,159 & 0,124 \\
\hline JSC "NK" LUKOIL" & 1,000 & 1,000 & 0,019 \\
\hline TOTAL & 3,257 & 1,940 & 3,008 \\
\hline The coefficient specific weight indicator & 0,40 & 0,24 & 0,37 \\
\hline
\end{tabular}

Thus, for the oil and gas industry the cost of fixed assets used plays a crucial role in assessing the effectiveness of the company. The general formula for the allocation of consolidated income tax between the budgets will be as follows:

$$
d=0,24 \cdot\left[\sum_{i=1}^{n} K_{S i} \cdot T_{i}\right]^{-1} \cdot K_{s i} \cdot T_{i}+0,40 \cdot\left[\sum_{i=1}^{n} A_{i}\right]^{-1} \cdot A_{i}+0,37 \cdot\left[\sum_{i=1}^{n} \Pi_{i}\right] \cdot \Pi_{i}
$$

We carry out the same calculations for other industries. Summary results are shown in Table 4.

TABLE IV THE CALCULATED AVERAGE VALUES OF PERFORMANCE INDICATORS FOR OTHER BRANCHES

\begin{tabular}{|c|c|c|c|}
\hline \multirow{2}{*}{ Branch } & \multicolumn{3}{|c|}{ Value ratio - the proportion of index } \\
\cline { 2 - 4 } & $\begin{array}{c}\text { Productivit } \\
\text { y of capital }\end{array}$ & $\begin{array}{c}\text { Working } \\
\text { efficiency }\end{array}$ & $\begin{array}{c}\text { Profitabilit } \\
\text { y of } \\
\text { production }\end{array}$ \\
\hline The steel branch & 0,41 & 0,24 & 0,35 \\
\hline $\begin{array}{c}\text { Telecommunicatio } \\
\text { ns branch }\end{array}$ & 0,37 & 0,31 & 0,32 \\
\hline $\begin{array}{c}\text { Banks and other } \\
\text { branches }\end{array}$ & 0,31 & 0,38 & 0,31 \\
\hline
\end{tabular}

Thus, we can conclude that the most important indicator of economic terms in oil and gas, iron and steel industries is the efficient use of fixed assets, due to the specifics of industries where there is a need for a large volume of fixed assets. In other areas, all three index almost equal. The use of computed ratios will also contribute to the implementation of the principle of social and environmental equity, as a preferential tax revenues in those subjects of Russian Federation, where the main production assets of enterprises are, will compensate for environmental damage and the removal of non-renewable natural resources.

\section{II.III. THE THIRD STAGE IN THE CONSTRUCTION OF GOVERNMENT AND TAXPAYERS INTERESTS' COORDINATION MODEL WITHIN THE CGT CREATION.}

Accounting degree of depressive regions in which consolidated group of taxpayers operates.

For the implementation of the social component of the proposed methodology, the degree of depression of the regions in which it operates consolidated group of taxpayers should be taken into account.

Assessment of the degree of depression of the region has a weighty significance in the analysis of socio-economic equity. There is a method of funds distribution intended for the additional financial support to depressed areas, which was approved by Resolution of the Russian Government dated 19 September 1998, Number 1112. The basis of calculation was adopted by the budgetary income-expenditure on socially significant items including funds not backed by funding sources for the reporting financial year, as well as accounts payable. In this case, the main criterion for determining the depression of the region is the estimated excess of expenditure over income in the budget amount (Пр), which is determined by the following formula:

$$
\Pi p=[P]^{-1} \cdot(P-Д) \cdot 100 \%,
$$

where 
P - socially significant costs to the budgets of Russian Federation subjects, increase of accounts payable, grants housing - communal services, etc.

Д - revenues of Russian Federation subjects in view of the financial assistance allocated from the federal budget, increased by a source to cover the budget deficit in the form of 20 per cent of the arrears.

In 2013, the draft of Federal Law N 91010-3 “About bases of federal support for depressed areas of the Russian Federation" was prepared where the criteria for inclusion in the region to this number got more accurate understanding and formal vocation. Some experts believe the criterion for depressive individual territories of Russia are the repeated decline in production in key sectors of the territories economy, which occurred during the last 15 years, the presence of unemployment in excess of the all-Russian level and lagging household income of the subsistence minimum. This is most evident in company towns through all over the economy activities [19].

According to the draft of the Federal Law N 91010-3 from 12.03.2003 criteria for inclusion of certain territories of Russian Federation to depression are the simultaneous combination of the following basic conditions:

1) Location within the administrative boundaries of one or more neighboring administrative units (including those, which are composed of one or more neighboring Russian Federation).

2) Uniformity economy of depressed areas (similar sectoral structure, level of development, the status of fixed assets, etc.) in each administrative unit (region, city), which is part of the territory.

3) Multiple (3 times or more) decline in production of key sectors of the economy that occurred in the territory over the past 12 years.

4) A significant (more than 1/4) lagging behind the average in Russian Federation indicators during the last 3 years: the unemployment rate (as a percentage of the economically active population); the ratio of cash income and subsistence level of the population.

The classification of depressive territory of the whole Russian Federation subject is permitted in exceptional cases, the following conditions taking place at the same time:

- it occupies an area no more than 40 thousand square kilometers;

- population is less than 500 thousand people;

- there is no more than two major industries, each of which undergoes multiple (3 or more times) decline in production over the last 12 years, in the territory of the entity;
- the share of subsidies given to the subject of Russian Federation should be at least 50 percent in the past 3 years in its consolidated budget.

Described methods are used for evaluation and formation of inter-budgetary relations. We offer to finalize the assessment of the level of depressive regions for taxation purposes. The value of the coefficient will depend on its size. The degree of depression is necessary to define by four levels: extremely depressed region $(\mathrm{Ks}=4)$, above average depressed region $(\mathrm{Ks}=3)$, below average depressed region $(\mathrm{Ks}=2)$ and not depressed region $(\mathrm{Ks}=1)$. Basic principles and methodology should be fixed at the legislative level.

Thus, the assignment of any of the regions depressive tax status will increase the income of the budget of CGT participants and thereby it will improve their socio-economic status and well-being of the population.

\section{THE EFFECTIVENESS OF THE PROPOSED MODEL EVALUATION.}

Based on the financial statements for 2014 the group of companies JSC "Oskol Electric Steel Works", which joined the CGT in 2016, it could have been told about the next target of calculated income tax in the regional budgets in 2015 .

TABLE V ANALYSIS OF CHANGES IN INCOME TAX REGIONS (THESE CALCULATIONS ARE MADE WITHOUT TAKING INTO ACCOUNT ASSESSMENT OF DEPRESSIVE REGIONS, KS = 1)

\begin{tabular}{|c|c|c|c|c|}
\hline $\begin{array}{c}\text { Names of } \\
\text { major } \\
\text { companies } \\
\text { CGT }\end{array}$ & $\begin{array}{c}\text { Planned tax } \\
\text { to the } \\
\text { regional } \\
\text { budget to the } \\
\text { CGT } \\
\text { (In } \\
\text { thous.rub.) }\end{array}$ & $\begin{array}{c}\text { Planned } \\
\text { tax to the } \\
\text { regional } \\
\text { budget } \\
\text { after the } \\
\text { creation of } \\
\text { CGT } \\
\text { (In } \\
\text { thous.rub.) }\end{array}$ & $\begin{array}{c}\text { Planned } \\
\text { tax to } \\
\text { the } \\
\text { regional } \\
\text { budget } \\
\text { after the } \\
\text { creation } \\
\text { of KGN } \\
\text { (new } \\
\text { method) } \\
\text { Thous. } \\
\text { roubles. }\end{array}$ & $\begin{array}{l}\text { Region } \\
\text { paying } \\
\text { the tax }\end{array}$ \\
\hline $\begin{array}{c}\text { JSC Oskol } \\
\text { Electric Steel } \\
\text { Works (JSC } \\
\text { OEMK) }\end{array}$ & 1433588 & 6470685 & $\begin{array}{r}5435 \\
550\end{array}$ & $\begin{array}{l}\text { Old } \\
\text { Oskol } \\
\text { (Belgor } \\
\text { od } \\
\text { region) }\end{array}$ \\
\hline $\begin{array}{c}\text { JSC Holding } \\
\text { Company } \\
\text { "Metalloinvest" }\end{array}$ & 3861309 & - & $\begin{array}{r}1949 \\
330\end{array}$ & $\begin{array}{c}\text { Mosco } \\
\text { w }\end{array}$ \\
\hline $\begin{array}{c}\text { JSC } \\
\text { Lebedinsky } \\
\text { Mining and } \\
\text { Processing } \\
\text { Plant (JSC } \\
\text { Lebedinsky } \\
\text { GOK) }\end{array}$ & 12695358 & 6268476 & $\begin{array}{c}6930 \\
955\end{array}$ & $\begin{array}{l}\text { Gubkin } \\
\text { (Belgor } \\
\text { od } \\
\text { region) }\end{array}$ \\
\hline $\begin{array}{c}\text { JSC } \\
\text { Mikhailovsky } \\
\text { GOK (OJSC } \\
\text { Mikhailovsky } \\
\text { GOK) }\end{array}$ & 3649247 & 3684696 & $\begin{array}{r}4076 \\
491\end{array}$ & $\begin{array}{c}\text { Zhelez } \\
\text { nogors } \\
\mathrm{k} \\
\text { (Kursk } \\
\text { region) } \\
\end{array}$ \\
\hline JSC Ural Steel & 828155 & 6043800 & $\begin{array}{r}4075 \\
330\end{array}$ & $\begin{array}{l}\text { Novotr } \\
\text { oitsk } \\
\text { (Orenb } \\
\text { urg }\end{array}$ \\
\hline
\end{tabular}




\begin{tabular}{|c|r|r|r|r|}
\hline & & & & region) \\
& & & & \\
\hline TOTAL & 22467656 & 22467656 & 22467 & \\
& & & 656 & \\
\hline
\end{tabular}

The new model allows to level the regions budget losses with the creation of CGT, where the enterprises with high performance are; more economically redistribution of tax revenues between the regional budgets takes place, as well as increase in social equity in tax revenues formation from different regions (Fig.1).

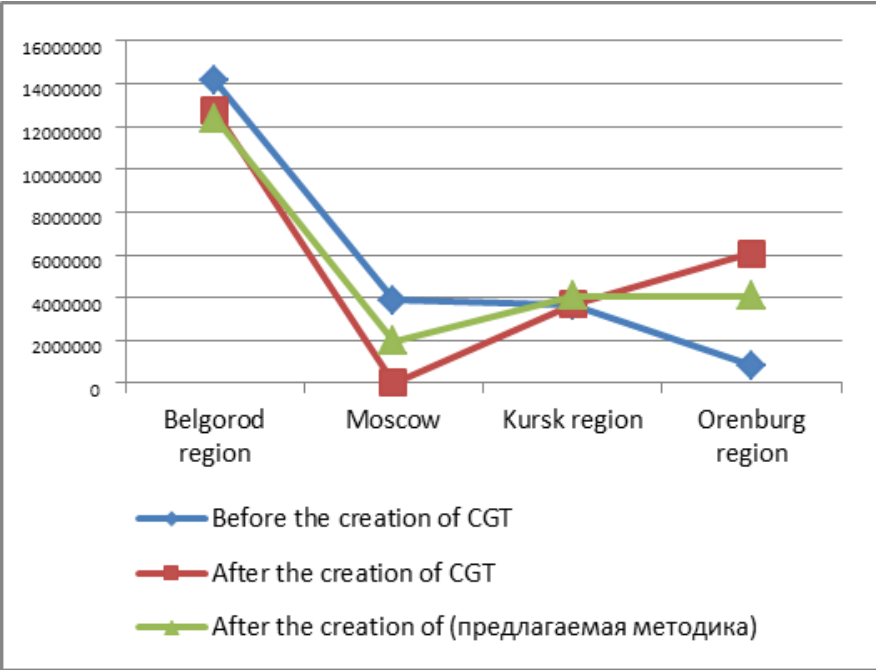

Fig. 1. Analysis of the effectiveness of the proposed model distributions of income tax CTG participants.

\section{CONCLUSION}

In our opinion, the proposed government and taxpayers interests' coordination model within the CGT creation model, based on the principle of social and economic equity, will lead to the unification of common efforts between management companies and regional authorities in order to improve the efficiency of enterprises, expressed in the creation of new jobs, attract investment, and benefits from development investments. It will also contribute to the development of regions social and economic situation and the welfare of society.

\section{ACKNOWLEDGEMENT}

The study was financially supported by Russian Humanitarian Science Foundation (RHSF) in the frame of the project for scientific studies (Modeling of conditions of the consolidation of tax liabilities to mitigate the conflict of interest of the state and taxpayers), project No. 15-32-01341.

\section{REFERENCES}

[1] K.A.Bannova, I.N.Dolgih, A.B.Zhdanova, N.V. Pokrovskaya, "Developing The Competitive Advantage Of Companies And Regions By The Creation Of Consolidated Groups Of Taxpayers", IBIMA, 2015, pp. 834-841.

[2] N.E. Aktaev, K.A. Bannova, A.S. Balandina, I.N. Dolgih, N.V. Pokrovskaia, U.A. Rumina, A.B. Zhdanova, K.N. Akhmadeev, "Optimization Criteria For Entry Into The Consolidated Group Of
Taxpayers In Order To Create An Effective Tax Mechanism And Improve The Social, Economic Development Of Regions In The Russian Federation", Procedia - Social and Behavioral Sciences, vol.166, 2015, pp. 30-35.

[3] A. V. Khaperskaya, K. A. Bannova, S. Z. Musina, "The Influence of Corporate Social Responsibility Program on the Economic Mechanism as a Whole", ICEM, 2015, pp. 390-393.

[4] E. N. Dyrina, K. A. Bannova, "Improvement in implementation of fiscal policy of Russia”, Procedia - Social and Behavioral Sciences, vol. 166, 2015, pp.58-61.

[5] U. A. Rumina, A. S. Balandina, K. A. Bannova, "Evaluating the effectiveness of tax incentives in order to create a modern tax mechanism innovation development", Procedia - Social and Behavioral Sciences, vol. 166, 2015, pp. 156-160.

[6] I. N. Dolgih, A. B.Zhdanova, K. A. Bannova, "The influence of taxation on small enterprise development in Russia", Procedia - Social and Behavioral Sciences, vol. 166, 2015, pp.216-221

[7] K.A.Bannova, Ju.A. Ryumina, A.S. Balandina, N.V. Pokrovskaia "Consolidated taxation of corporations", Tomsk : STT, 2015, 190 p.

[8] A. Pogorletskiy, and F.Söllner, "The Russian tax system and its international competitiveness", Intereconomics, vol.43, Issue 5, 2008 , pp.288-297.

[9] I. Mayburov, Y. Leontyeva, "Transport tax in Russia as a promising tool for the reduction of airborne emissions and the development of the road network", WIT Transactions on Ecology and the Environment, 2015 .

[10] V. Ivanov, V. Mishchenko, and O. Maliutin, "International experience of inflation targeting: model of success for Ukraine", Actual Problems of Economics, vol. 166, № 4, 2015, pp. 414-425.

[11] JONATHAN R. KESSELMAN, "Taxpayer Behavior and the Design of a Credit Income Tax", Income-Tested Transfer Programs, 1982, pp. 215-290.

[12] GCPL consolidated net up $2 \%$ on higher tax, operating expenditure // Focus on Surfactants, vol. 2013, Issue 12, 2013, pp. 7

[13] Carmen Comaniciu , Liliana Bunescu " Taxation in Romania - Some Positive Aspects", Procedia Economics and Finance, vol. 6, 2013, pp.615-620.

[14] "Asian Paints consolidated net profit for the quarter increases by $11.8 \%$ " Focus on Powder Coatings, vol. 2015, Issue 3, 2015, pp. 2

[15] Aziz Jaafar, John Thornton, “ Tax Havens and Effective Tax Rates: An Analysis of Private versus Public European Firms", The International Journal of Accounting, vol. 50, Issue 4, 2015, pp. 435-457.

[16] "Asian Paints consolidated net sales for 2Q 2010 increases by 16.8\%", Focus on Powder Coatings, vol. 2010, Issue 2, 2010, pp. 5

[17] Don Herrmann, Tatsuo Inoue, Wayne B Thomas “ PREDICTING CONSOLIDATED EARNINGS IN JAPAN: THE INCREMENTAL USEFULNESS OF SUBSIDIARY EARNINGS", Advances in International Accounting, vol. 16, 2003, pp. 85-103

[18] Qingyue Meng, Hai Fang, PhDa , Xiaoyun Liu, Beibei Yuan, Jin Xu, "Consolidating the social health insurance schemes in China: towards an equitable and efficient health system", THE LANCET, Vol. 386, Issue 10002, 2015, pp. 1484-1499.

[19] I.S. Antonova, O.A. Negodina, D.D. Vavilov, "Russian company town: creteria and diversification results", IBIMA, 2015, pp. 2181-2187

[20] N. Chistyakova, V. Spitsin, T. Gromova, N. Shabaldina, A. Dudnikova, "Comparative Investment Analysis of Industries Development in Russia and Germany". Proceedings of the 2015 International Conference on Education Reform and Modern Management, Atlantis Press; 2015; Available from: http://dx.doi.org/10.2991/ermm-15.2015.98

[21] I.E. Nikulina, A.A. Tarabanovsky "Monitoring Analysis" and "monitorcriteria" in the system of financial planning of the Autonomous Educational Institution of Higher Professional Education", Fundamental Research, 2009, № 1, pp. 82-88.

[22] I. P. Nuzhina, O. B. Yudakhina, E. I. Kotik , E. G. Matyugina "Ecologization of Management Functions as a Factor of Sustainable Development of Construction Industry in Russia”, ICEM2015, 2015, pp. 414-417 
